\title{
Celebrity Endorsements and Customer Patronage
}

\section{A Study of Nigeria Bottling Company, Port Harcourt, Rivers State}

\author{
Obiageli. A. Nnamocha ${ }^{1} \&$ Tutah T. Chukundah ${ }^{2}$ \\ ${ }^{1}$ Department of Marketing, Faculty of Business Administration, Imo State University Owerrie, Nigeria \\ ${ }^{2}$ Department of Marketing, Faculty of Business Studies, Ignatius Ajuru University of Education, Rumuolumeni, \\ Port Harcourt, Nigeria \\ Correspondence: Obiageli. A. Nnamocha, Department of Marketing, Faculty of Business Administration, Imo \\ State University Owerrie, Nigeria.
}

Received: November 16, 2018; Accepted: December 3, 2018; Published: December 13, 2018

\begin{abstract}
This research is on the relationship between celebrity endorsements and customer patronage, using the Nigeria Bottling Company (NBC) Port Harcourt as the unit of study. The survey design was adopted, using a structured questionnaire as the instrument for data collection. Two research questions and two hypotheses guided the study. The hypotheses were tested using the z-test statistic at 0.05 level of significance. It was found among others that when celebrities who are outstanding, have integrity and are knowledgeable endorse a product, customer patronage is enhanced. In addition, it was found that the attractiveness of a celebrity, consistent use of a celebrity and multiple promotional coverage enhance customer repeat purchase and increased brand loyalty. Based on the findings, it was held that there is significant relationship between endorsement coverage and repeat purchase of beverages, as well as a significant relationship between frequency of endorsements and customer brand loyalty of beverages. Consequently, recommendations were proffered that organizations should seize the opportunity of using celebrity endorsements in promoting their products, with emphasis on reliable, credible and well-accepted celebrities so as to achieve customer patronage and brand loyalty. In conclusion, organizations are advised be careful in their choices of celebrities, so as to have the right 'personality' of celebrity who is worth the amount paid for the services rendered.
\end{abstract}

Keywords: celebrity endorsements, customer patronage, repeat purchase, brand loyalty

\section{Introduction}

This study is focused on celebrity endorsements and customer patronage of beverages in Port Harcourt, Nigeria. The practice of celebrity endorsements has been proliferated over time, becoming a pervasive element in the promo-tools and has grown to become a multi-million industry. Interestingly, most adverts have celebrities that project the products or services and this is believed to havesome influence on the buyers and customers of these products and services. Celebrity endorsement has indeed been established as one of the most popular tools of advertising in recent times (Kenyon, Weeloon and Richardson, 2012). It has become a trend and perceived as a winning formula for product marketing and brand building. Advertisements that use celebrity endorsers enjoy high popularity among brand managers and consumers tend to keep buying the brand over and over again, since most advertisements employing celebrity endorsers enjoy high popularity among brand managers (Amos, Holmes and Strutton, 2008).

Basically, a celebrity is described as any famous and influential person that is admired and much spoken about by people in a society (Choi and Rifon, 2007). A celebrity endorser is any individual who enjoys public recognition and who uses this recognition on behalf of a product or service by appearing with it in an advertisement (McCracken, 1989). The use of celebrities has been adopted by various advertising agencies and is used in the advertisement of products and services. Celebrity endorsements influence brand image through a transfer of meaning from the endorser to the brand, as communication activities establish a pattern of connectivity between the image of the celebrity and the image of the brand. According to Bishop (2000), a marketing expert, when you get a celebrity to endorse your company or sign a licensing agreement, you benefit from customer awareness of the product, which could include the perception of the quality, educational value or a certain image. If a celebrity is endorsing the product of a well-known entity, people tend to assume it must be a good company to deal with. 
To Crutchfield (2010), everybody lives by selling something, but in the light of the attendant risks, one wonders if celebrity endorsement deals are still worth it. The fact remains that if you put a face to a name, it is more likely that you will remember it and marketers know that the same goes with having celebrities host their brands. No doubt, brand loyalty is the target all marketers seek to achieve, hence marketers spend a lot of effort and money to first identify the true image of the brand and then, find the suitable person to represent this brand. They are not satisfied with ordinary representatives, on the contrary, they seek better-known advocates. For instance, LeBron James is one of the top three paid athletes in the world and generates a brand halo (Udo, Nwulu and Stella, 2015), which implies promoting a unique, relevant and sustainable brand attribute that might be hard to attain otherwise. Nike's rapid success in the golf category was principally because golfers wanted to associate with the number-one golfer in the world and opted to build reciprocity into the partnership by supporting the celebrityendorser's brand. Thus, celebrity endorsement has become the ground for innovating the product/service offering, thereby giving a brand a touch of glamour (Ola, 2001).

\subsection{Statement of the Problem}

Nigeria as a country is said to be densely populated with about 198 million people (NPC, 2018) and consumers are exposed to about one thousand promotional messages on average per day (Ike, 2015), although the audience tends to forget about $80 \%$ of the information within 24 hours (Ike, 2015). This is worrisome since about only $20 \%$ of the messages receive the desired attention expected by the marketer. It is becoming a challenge for marketers to break through the advertising clutter and hold the subject's attention, as consumers' attention span has decreased from twelve seconds in 2000 to eight seconds in 2013, shorter than that of a goldfish, which is at nine seconds (Microsoft Corporation 2015).

In order to deal with this, marketers have adopted the use of celebrity endorsements to reinforce their marketing messages, so as to improve the attention, retention and interest exhibited by their audiences. It has been noted that customers' attitudes regarding brands and products are well enhanced by celebrities, but whether this generates patronage or repeat purchase intention and brand loyalty is not so clear (Byrne and Whitehead, 2003).

It is against this background that this study is set to investigate the empirical relationship between celebrity endorsements and customer patronage of beverages in the Nigerian environment using Port Harcourt as the city of study.

\subsection{Conceptual Framework}

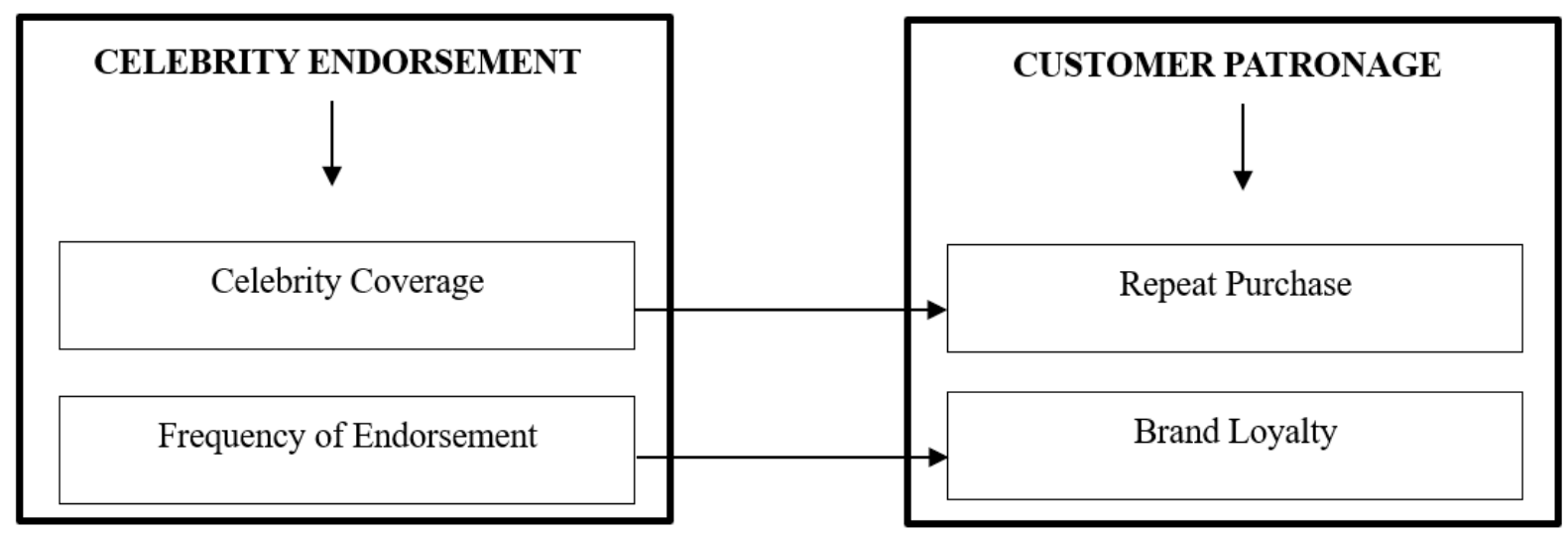

Source: Researchers' Desk, 2018

\section{Research Hypotheses}

The following hypotheses guided the study:

Ho2: There is no significant relationship between endorsement coverage and the repeatpurchase of beverages.

Ho3: There is no significant relationship between frequency of endorsements andbrand loyalty of beverages.

\subsection{Review of Related Literature: Conceptual Review}

\subsubsection{The Concept of Celebrity Endorsements}

Celebrity branding also known as celebrity endorsement, is a form of publication by portraying a well-recognized sports or entertainment celebrity to be a brand ambassador for a company or firm, and by using their social status to 
promote a service or product (Udo, Nwulu, and Stella, 2015). Celebrity endorsement is an important concept that has become a common marketing strategy to link and transfer (directly or indirectly) the qualities of the celebrity that are aspired to and liked by the consumer, such as physique, health or lifestyle to the brand (Leslie, 2011). This is done so that an association between the brand and celebrity is formed in the mind of the consumer. In addition, the approach is necessary to increase the attractiveness of the product and likelihood of influencing consumer preferences and purchase intentions regarding that particular product (Leslie 2011). People are often riveted by and obsessed with celebrities and at times feel familiar with them because celebrities often reinforce their desired image or self-identity (Nayar, 2009).

Three types of endorsements exist, namely: explicit, implicit and imperative. Explicit endorsement relays the message that the celebrity endorser only endorses the product and does not utilise it. Implicit endorsement occurs when the message relayed informs the consumer that the endorser utilises the product and in an imperative endorsement, the endorser tells the consumer to use the product (Seno and Lukas 2007).

\subsubsection{Celebrity Endorsement Coverage and Repeat Purchase of Beverages}

To Chattopadhyay, Shivani and Krishan (2009), the recognition of celebrities in advertising campaigns can make an advertisement to stand out from the advertising clutter of competitors, as linking celebrities with certain brands may assist in enhancing a brand in the mind of the consumer through recall and brand associations, thereby increasing the brand equity. Marketers spend substantial amounts of money on celebrity endorsements with the hope that these celebrities will inspire consumers to purchase their products as celebrities are deemed to be people that others look up to and desire to emulate (Nayar, 2009). Okorie (2010) has reasoned that advertising is the means of promoting brands and creating unshakeable consumer preference for the brand. Endorsement coverage brings to bear an estimated number of customers or prospects of a brand reached by an advertisement or commercial. This number depends on the readership (or listenership or viewership) of the media vehicle.

\subsubsection{Celebrity Frequency of Endorsement and Brand Loyalty}

Celebrity endorsement is considered as one of the most known marketing tools in the beverage industry (Chio and Rifon, 2007) and is considered as a winning strategy to build a unique identity for the brand. Being in a highly competitive environment, organizations seek to create the concept of brand loyalty in their customers' mind as a way to protect their existence as well as maximize their profitability. Frequency in celebrity usage in adverts is the number of times a person must be exposed to an advertising message before a response is made and before exposure is considered wasteful. Effective frequency is quite controversial, since many people have their own definition on what this word means. There are also numerous studies with their own models as to what the correct number is for effective frequency. Jones (2009) states that effective frequency can mean that a single advertising exposure is able to influence the purchase of a brand. Banasiewicz (2005),Dick and Badu, (1994), Chattopadhyay, Shivani and Krishan(2009), Bandyopadhyay and Martell (2007) and Chaudhuri and Holbrook (2001) while researching on the various forms of loyalty.

(behavioural and attitudinal) agree that the adoption of celebrities has the power to drive these forms of loyalty.

\subsection{Theoretical Review}

This study is anchored on the AIDA Model adapted from Nnedu (1998), represented as:
Attention

The phrase AIDA, in marketing communication was coined by Lewis in the late 1800s. The model is about the different phases through which a consumer goes before buying a product or service and it is advised that marketers follow this model to fetch new customers for their products. This model is widely used in today's celebrity endorsement adverts to create the needed awareness for buyers to patronize.

The first role of an advertisement is to attract the customers. Once an ad gains attention, it has to invoke interest towards the product in the minds of the consumers. After creating an interest, the ad has to bring about a desire in the consumers' minds to use the product and finally the consumer should be led to take a favorable action towards the product by ultimately purchasing the product. This sequence is usually adopted in celebrity endorsements.

\subsection{Empirical Review}

Dissanayake and Weerasiri (2017) carried out a study on the impact of perceived effectiveness of celebrity endorsement on perceived brand personality, noting that the application of celebrity endorsement has been an intensive practice due to head-on brand competitions, which forces companies to depend on celebrities as one of the responsive strategies. They considered it crucial to examine the absolute effectiveness of celebrity endorsement towards the endorsed brands, as to rationalize marketing expenses incurred. They cited McCutcheon, 
Lange, and Houran, (2002) introducing the Meaning Transfer Model, stating that the meaning of an adis derived by what a celebrity transfers to the endorsed brand via three processes. Firstly, the meaning ascribed to an endorsement will move to the endorsed brand, then the endorsement converts the particular product into a specific brand personality and finally, the consumer engages in a consumption behavior with the endorsed brand. This is in conformity with Ohanian's view (1991) that familiarity, attractiveness, likability and similarity of the celebrity are the properties that influence the effectiveness of the endorsement for a brand.

Adeiza and Adepoju (2017) investigated the effect of celebrity endorsement on consumer patronage of GSM services, adopting survey design and using a questionnaire to gather data from 395 consumers in Kano metropolis. Pearson's Product-Moment Correlation Coefficient test was conducted. Weighted average was also used to analyze the relative influence of each aspect of celebrity association as they affect consumer patronage. It was found that celebrity endorsement has a statistically significant negative effect on consumer patronage of GSM service providers.

Another study byArora and Sahu (2014)used the TEARS model as the determinants of the perceived effectiveness of celebrity endorsement. TEARS means Trust-worthiness, Expertise, Attractiveness, Respect and Similarity as the variables that drive effective endorsement. They adopted the inductive approach in testing existing models, and used convenient sampling methods for data collection from 160 respondents who represent socio-demographic diversities (152 responses were considered in the final analysis). A structured questionnaire was used as the data collection instrument since it selected survey method as the research approach. Data analysis was supported by descriptive and inferential statistical sources. SPSS-20 software package was used for the data analysis and charts were used to present the data. Descriptive statistics were applied for the calculation of mean, standard deviation and variances for the independent and dependent variables. The correlation test was applied to determine the relationship between brand personality and the determinants of effective celebrity endorsement using TEARS model. Regression was used to identify the strength of the relationship between the two variables and ANOVA test was conducted, identifying the significance of the relationship. It was found that trustworthiness, similarity, expertise and attractiveness have positive moderate relationships with the brand personality. However, the reputation of the celebrity showed a weak positive relationship with the brand personality.

\section{Research Gap}

Celebrity endorsement no doubt helps in increasing recall value of endorsed brand. Though some studies on celebrity endorsement exist, notably on the impact of perceived effectiveness of celebrity endorsement on perceived brand personality (Dissanayake and Weerasiri 2017), none has paid specific attention to the study of the relationship between celebrity endorsements and customer patronage of beverages in the Nigerian environment. Research interest on this issue seems neglected as there are no records considering the endorsement associated cost, coverage and frequency influences on customer patronage beverages. Hence, the credence for this very study, drawing our inference from Coca-Cola as a major marketer of beverages.

\section{Methodology}

This study adopted the survey design as (Orodho, 2004) asserts that to produce information that is of interest to policy makers in business, a survey design is helpful. This involved collection of information by administering questionnaire and interviewing a sample of individuals. The descriptive study was undertaken in order to ascertain and be able to describe the characteristics of the variables of interest in a situation (Kothari, 2008). The total work force of Nigeria Bottling Company (NBC) in Port Harcourt, Rivers State including factory and field workers formed the target population for the study. However, the sample for this study is made up of 324 management staff of various divisions and strata of the company in Port Harcourt Depot as well as 1200 customers who are the direct buyers and marketers of the products of the company, and are registered with the company (NBC, Port Harcourt Depot, 2018). Simple random sampling technique was used to reach the respondents and a structured questionnaire used for the generation of data. The degree of reliability of the questionnaire was based on a test-retest. In addition, the Cronbach alpha test was carried out and this yielded a value of 0.79 , which is considered valid according to Nunnally and Bernstein (2009),Sekaran, and Bougie (2010).

\section{Analysis of Data}

The sample size is 400 ; made up of 150 management staff and 250 customers. The responses elicited from the two groups via the research instrument administered and retrieved from them were used to analyze the hypotheses for the study. 
Table 1. Summary of Questionnaire Responses

\begin{tabular}{lllllllll}
\hline Questionnaire Items & SA & $\mathbf{A}$ & $\mathbf{U}$ & $\mathbf{D}$ & $\mathbf{S D}$ & Total & $\begin{array}{l}\text { Mean } \\
(\overline{\boldsymbol{X}})\end{array}$ & $\begin{array}{l}\text { Actual } \\
\text { means }\end{array}$ \\
\hline Celebrity's presence in interactive social networks & 100 & 30 & 10 & 7 & 3 & 150 & 4.45 & 133.40 \\
enhance customer repeat purchase of beverages & 110 & 60 & 40 & 30 & 10 & 250 & 3.92 & 196.00 \\
The use of celebrities on various promotional media & 80 & 30 & 25 & 10 & 5 & 150 & 4.13 & 124.00 \\
enhances repeat purchase of beverages & 90 & 70 & 55 & 25 & 10 & 250 & 3.82 & 191.00 \\
The use of a celebrity to create awareness enhances & 68 & 42 & 20 & 15 & 5 & 150 & 4.02 & 120.60 \\
repeat purchase of beverages & 95 & 75 & 50 & 20 & 10 & 250 & 3.90 & 195.00 \\
The regular and consistent appearance of well-known & 70 & 50 & 20 & 5 & 5 & 150 & 4.17 & 125.00 \\
celebrities enhance repeat purchase of beverages & 130 & 60 & 30 & 20 & 10 & 250 & 4.12 & 206.00 \\
\hline
\end{tabular}

Source: Survey Data, 2018

Table 1 revealed that all the mean ratings of all the attributes measured are greater than the standard average value of 3.00, therefore, are all considered for the analysis of data. Hence, management weighted mean response of 4.45 and customers' weighted mean response of 3.92 indicates that celebrity's presence in interactive social networks enhance repeat purchase of beverages. It equally revealed management weighted mean response of 4.13 and customer weighted mean response of 3.82, indicating that celebrities used on various promotional media enhance repeat purchase of beverages. Again, the use of a celebrity to create awareness enhances repeat purchase of beverages as indicated by management weighted mean response of 4.02 as well as customers weighted mean response of 3.90. Even so, management weighted mean response of 4.17 and customers' weighted mean response of 4.12 indicated that regular and consistent appearance of well-known celebrity enhances repeat purchase of beverages.

\section{Test of Hypotheses}

Ho1: There is no significant relationship between endorsement coverage and repeat purchase ofbeverages

6.1 Results

Table 2. Paired Samples Statistics

\begin{tabular}{llllll}
\hline & & Mean & N & Std. Deviation & Std. Error Mean \\
\hline Pair 1 & Endorsers' Coverage & 197.00 & 400 & 20.274 & 2.277 \\
& Repeat Purchase & 125.75 & 400 & 24.728 & .057 \\
\hline
\end{tabular}

This gives the descriptive statistics for each constructs

Table 3. Paired Samples Correlations

\begin{tabular}{lllll}
\hline & & $\mathrm{N}$ & Correlation & Sig. \\
\hline Pair 1 & Endorsers' \& Repeat Purchase & 400 & .844 & .003 \\
\hline
\end{tabular}

The correlation between the two constructs $r=0.844$ with $p$-value is less than 0.005 which is 0.001 .

Table 4. Paired Samples Test

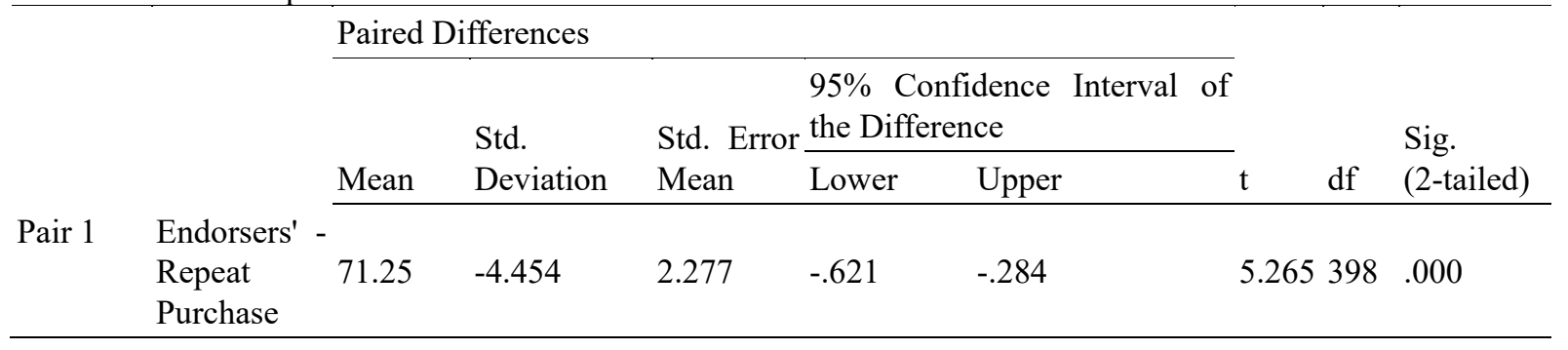


The mean difference of the two constructs (Endorsers' Coverage and Repeat purchase) is 71.25 and a standard deviation of -4.454 . Since the t-calculated $=2.277$ is greater than the $t$-tabulated (1.967) and the p-value is 000 which is less than 0.05 , we reject the null hypotheses and conclude that there is a significant relationship between endorsement coverage and repeat purchase of beverages.

$\mathrm{Ho}_{2}$ : There is no significant relationship between frequency of endorsements and customers brand loyalty of beverages

Table 5. Paired Samples Statistics

\begin{tabular}{llllll}
\hline \multirow{2}{*}{ Pair 1 } & Frequency of Endorsement & Mean & $\mathrm{N}$ & Std. Deviation & Std. Error Mean \\
\cline { 2 - 6 } & 127.40 & 400 & 17.841 & .054 \\
& Customers Brand Loyalty & 185.73 & 400 & 20.234 & .061 \\
\hline
\end{tabular}

This gives the descriptive statistic for each constructs.

Table 6. Paired Samples Correlations

\begin{tabular}{|c|c|c|c|}
\hline & $\mathrm{N}$ & Correlation & Sig. \\
\hline Pair 1 & $\begin{array}{l}\text { Frequency of Endorsement \& } 400 \\
\text { Customers Brand Loyalty }\end{array}$ & .659 & .001 \\
\hline
\end{tabular}

The correlations between the two constructs, $r=0.659$ with $p$-value less than 0.05 which is 0.001 .

Table 7. Paired Samples Test

\begin{tabular}{|c|c|c|c|c|c|c|c|c|}
\hline & \multicolumn{5}{|c|}{ Paired Differences } & & & \\
\hline & & \multirow{2}{*}{$\begin{array}{l}\text { Std. } \\
\text { Deviation }\end{array}$} & \multirow{2}{*}{$\begin{array}{l}\text { Std. } \\
\text { Error } \\
\text { Mean }\end{array}$} & \multicolumn{2}{|c|}{\begin{tabular}{llr}
$95 \%$ & \multicolumn{2}{c}{ Confidence } \\
Interval of the \\
Difference
\end{tabular}} & \multirow[b]{2}{*}{$\mathrm{T}$} & \multirow[b]{2}{*}{$\mathrm{df}$} & \multirow{2}{*}{$\begin{array}{l}\text { Sig. } \\
\text { (2-tailed) }\end{array}$} \\
\hline & Mean & & & Lower & Upper & & & \\
\hline Pair 1 & $\begin{array}{l}\text { Frequency of } \\
\text { Endorsement - } 58.33 \\
\text { Customer Brand } \\
\text { Loyalty }\end{array}$ & 1.493 & 1.939 & .066 & .359 & 2.847 & 399 & .004 \\
\hline
\end{tabular}

The mean difference of the two constructs (Frequency of endorsement and Customer Brand Loyalty) is 58.33 with a standard deviation of 1.493 . Since the t-calculated $=2.847$ is greater than the t-tabulated (1.967) and the p-value is 004 is less than 0.005 , we reject the null hypotheses and conclude that there is a significant relationship between frequency of endorsement and customer brand loyalty of beverages

\section{Discussion of Findings}

This study on celebrity endorsement and customer patronage revealed that when celebrities endorse a product, it enhances customer purchases. Such celebrities have integrity, are very outstanding and knowledgeable, and so, their endorsement of beverages influence customer purchases positively.

This is in conformity with the views of Diehi and Terlutter (2006) that a successfully endorsed advertising campaign by a reputable celebrity has the ability to achieve the advertising objective of boosting product or service sales.

This study further reveals that attractiveness of a celebrity, regular use of a popular celebrity and through promotional coverage enhances customer repeat purchase. Specifically, celebrity presence in the interactive social 
networks enhances repeat purchase of beverages as indicated by the management staff weighted mean response of 4.13 and customers weighted mean response of 3.82 are evidence of this.

Again, the use of a celebrity to create awareness enhances repeat purchase as indicated by management staff weighted mean response of 4.02 as well as customers weighted mean response of 3.90. Even so, the consistent appearance of well-known celebrities enhances repeat purchase of beverages as revealed by management staff weighted mean response of 4.17 and customers' weighted mean response of 4.12. This corroborates the views of Chan, Ng, and Luk (2013) as well as the results of the tested corresponding hypothesis in which the t-calculated value of 2.620 is greater than t-critical value of 2.447 at 0.05 level of significance.

This study found that celebrity endorsement enhances customer loyalty as attested to by the respondents.It was revealed that more frequent use of celebrity endorsers enhances customer loyalty as indicated by management staff weighted mean response of 4.23 as well as customers weighted mean response of 3.88 .

It was equally found from management staff weighted mean response of 4.35 and customers weighted mean response 3.66 that increased use of celebrity endorsements enhance brand loyalty, and that consistent on-line use of a celebrity enhances customer loyalty as indicated by management staff and customers weighted mean response of 4.35 and 3.66 respectively. Interestingly, this finding is in line with the corresponding hypothesis test statistics result since t-calculated value of 7.627 is greater than t-tabulated value of 2.776 at 0.05 level of significance.

However, consumers could switch brands due to openness to change and associated power of communication of the endorser to change beliefs, ideas and shifts about brands, promoting brand switch and changing loyalty status (Choi and Rifon 2007).

These findings support a study by Chaturvedi (2014), which revealed that a celebrity involved in a scandal discourages consumer purchase of his endorsed product. This emphasizes the need for endorsers to maintain a positive image so as to sustain brand loyalty.

\section{Recommendations}

Based on the findings of this study, the researchers recommend as follows:

1. Organizations should seize opportunity of using celebrity endorsements in advertising their products with emphasis on reliable, credible, outstanding and well accepted celebrities so as to achieve customer purchase, repeat purchase and loyalty.

2. Organizations should however be critical in the selection of celebrities as to have the right 'personality' of celebrity in order to ensure that the celebrity is 'worth' the amount paid for the services rendered.

3. Celebrity endorsements should be adopted within multiple promotional outlets so, as to achieve the needed synergy in effective marketing promotions.

\section{Conclusion}

Based on the findings of the study, the following conclusions are made:

There is significant relationship between celebrity endorsement cost and customer purchase of beverages.

There is significant relationship between endorsement coverage and repeat purchase of beverages.

There is significant relationship between frequency of endorsements and customer brand loyalty of beverages.

These are in agreement with the views of Diehl and Terlutter (2006) that a successfully endorsed advertising campaign by a reputable celebrity has the ability to achieve the advertising objective of boosting product or service sales and assisting an organization in achieving competitive advantage, thereby ultimately leading to the achievement of organizational goals and thus, ensuring organizational survival.

\section{References}

Amos, C., Holmes, G., \& Strutton, D. (2008). Exploring the relationship between celebrity endorser effects and advertising effectiveness: A quantitative synthesis of effect size. International Journal of Advertising, 27(2), 209-234. https://doi.org/10.1080/02650487.2008.11073052

Agadoni, L. (2015). The Effect of Celebrities in Advertisements. (Retrieved on15 December 2015).

Atkinson, A., Elliott, G., Bellis, M., \& Sumnall, H. (2011). Young People, Alcohol and theJoseph Rowntree Foundation. Liverpool: Liverpool John Moores University.

Baron, R. A., Branscombe, N. R., \& Byrne, D. (2009). Social Psychology. $12^{\text {th }}$ Edition. Boston: Allyn and Bacon.

Belch, M., \& Belch, G. E. (2003). Advertising and Promotion.. New Delhi: Tata McGraw-Hill. 
Bezuidenhout, F. J. (2011). A Reader on Selected Social Issues. Pretoria: VanSchaikPublishers. Bukszpan D 2015. 6 Celebrity Endorsements That Enraged Consumers. (Retrieved on 10 December 2015).

Choi, S. M., \& Rifon, N. J. (2007). Who is the Celebrity in Advertising's? Understanding Dimensionsof Celebrity Images. The Journal of Popular Culture, 40(2), 10-13. https://doi.org/10.1111/j.1540-5931.2007.00380.x

Chan, K., Ng, L. Y., \& Luk, E. K. (2013). Impact of celebrity endorsement inadvertising onbrandimage among Chinese adolescents. Young Consumers, 14(2), 167-179. https://doi.org/10.1108/17473611311325564

Crutchfield, D. (2010). Celebrity Endorsements Still Push Product: Why, in the Era of SocialMedia,the Rewards Continue to Outweigh the Risks. (Retrievedon 12 December 2015).

Chattopadhyay, T., Shivani, S., \& Krishan, M. (2009). Determinants of brand equity - Ablue print for building strong brands: A study of the automobile segment in India.African Journal of Marketing Management, 1(4), 109-121.

Duruiheoma. (2018). The National Population Commission (NPC), Vanguard Media Limited, Nigeria.

Daneshvary, R., \& Schwer, R. K. (2002). The Association Endorsement andConsumers'intention to Purchase. Journal of Consumer Marketing, 17(3), 203-213. https://doi.org/10.1108/07363760010328987

Dissanayake, D. M. R., \& Weerasiri, R. A. S. (2017). The Impact of Perceived Effectiveness of Celebrity Endorsement on Perceived Brand Personality. J. Accoun Mark, 6(3), 244.

Diehl, S., \& Terlutter, R. (2006). International Advertising and Communication, CurrentInsights and Empirical Findings. Germany: Der Deutsche Universitats. https://doi.org/10.1007/3-8350-5702-2

Elberse, A., \& Verleuni, J. (2011). The economic value of celebrity endorsements. Journal of Advertising Research (Forthcoming).

Fieldgate, I., Jeffrey, R., Madinane, M., Ebrahim, Y., \& Soobyah, L. (2013). Economic Impactof an Advertising Ban on Alcoholic Beverage. Econometrix PTY (LTD).

Garthwaite, C. L. (2014). Demand spillovers, combative advertising, and celebrityendorsements.American Economic Journal: Applied Economics, 6(2), 76-104. https://doi.org/10.1257/app.6.2.76

Harris, H., Moffit, H. E., \& Squires, R. C. (2010). The Obama Effect-Multi DisciplinaryRenderings of the 2008 Campaign. New York: State University of New York Press.

Irwin, T. G. (2013). Endorsements Don't Earn Trust For Marketers. (Retrieved on 15 December2015).

Hung, K., Chan, K. W., \& Tse, C. H. (2011). Assessing celebrity endorsement effects in China aconsumer celebrity relational approach. Journal of Advertising Research, 51, 608-623. https://doi.org/10.2501/JAR-51-4-608-623

Ike, B.B. (2015). Influence of celebrity endorsement on consumer brand preference of selectedbeverage brands in Nigeria.Being a dissertation presented to the department of marketing, university of Nigeria, Enugu campus.

Jansson-Boyd, C. V. (2010). Consumer Psychology. England: Open University Press McGrawHill.

Kardes, F., Cronley, M., \& Cline, T. (2008). Consumer Behaviour. Canada: Cengage Learning.

Kell, J. (2015). Celebrities Making Money Off Your Liquor Shelf. (Retrieved on17 December2015).

Kothari, C. R. (2008). Research Methodology, Methods and Techniques (2nd ed) 109-110). NewDelhi.

Kenyon, A. T., Wee Loon, N. L., \& Richardson, M. (2012). The Law ofReputation andBrands in the Asia Pacific. New York: Cambridge University Press. https://doi.org/10.1017/CBO9781139084604

Khan, M. (2006). Consumer Behaviour and Advertising Management. New Delhi: New AgeInternational Publishers.

Kotler, P., \& Armstrong, G. (2012). Principles of Marketing. 14th Edition. NewJersey:Pearson Prentice Hall.

Lennox, C. (2014). They Be Drankin': 21 Celebrity Alcohol Endorsements (Retrieved on 10December 2015).

Leslie, L. Z. (2011). Celebrity in the 21st Century. California: ABC.

Meeker, W. Q., Hahn, G. J., \& Escobar, L. A. (2017). Statistical Intervals: A Guide forPractitioners and Researchers (2nd Edition). John Wiley \& Sons. https://doi.org/10.1002/9781118594841

Marketing Charts Staff. (2014). How Influential Are Celebrities? (Retrieved on 10December2015). 
McCutcheon, L. E., Lange, R., \& Houran, J. (2002). Conceptualization and Measurement of Celebrity Worship. British Journal of Psychology, 93, 67-87. https://doi.org/10.1348/000712602162454

Microsoft Corporation. (2015). How Does Digital Affect Canadian Attention Spans? (Retrievedon 15 December 2015).

Nayar, P. K. (2009). Seeing Stars Spectacle, Society and Celebrity Culture. New Delhi: Sage Publications India.

Nunnally, J. C., \& Bernstein, I. H. (1994). Psychometric theory (3rd ed.). New York: McGraw-Hill. (8)

Nielsen. (2015). Global Trust in Advertising: Winning Strategies for an EvolvingMediaLandscape.(Retrieved on 15 December 2015).

Nyarko, I. K., Asimah, V., Agbemava, E., Kafui, E., \& Tsetse1, E. K. (2015). The Influence of Celebrity Endorsement on The Buying Behaviour of the Ghanaian Youth: A Study of Fan Milk Ghana Ads, Published by European Centre for Research Training and Development UK (www.eajournals.org). International Journal of Business and Management Review, 3(11), 1-16.

Nnedu, E. E. I. (1998). Advertising and sales promotion: Theory and Practice, PortHarcourt,Paragraphics

Orodho, J. A. (2004). Elements of Education and Social Science Research Application in Education and Social Sciences, Masola Publishers, Nairobi Kenya.

Ohanian, R. (1991). The Impact of Celebrity Spokesperson's Perceived Image onConsumers'Intentionto Purchase. Journal of Advertising Research, 31, 46-52

Okonkwo, U. (2013). Luxury Brands and Celebrities: An Enduring BrandRomance. (Retrievedon21 December 2015).

Rogers, W. M., Schmitt, N., \& Mullins, M. E. (2002). Correction for unreliability ofmultifactor measures: Comparison of alpha and parallel forms approaches.

Roy, S. (2012). To use the obvious choice: Investigating the relative effectiveness of anoverexposedcelebrity. Journal of Consumer Research, 22, 15-17.

Seno, D., \& Lukas, B. A. (2007). The equity effect of product endorsement by celebrities: Aconceptual framework from a co-branding perspective. European Journal of Marketing, 41, 121-134. https://doi.org/10.1108/03090560710718148

Sekaran, U., \& Bougie, R. (2010). Research Methods for Business, (5th ed) USA: SagePublications.

Spry, A., Pappu, R., \& Cornwell, T. B. (2011). Celebrity Endorsement Brand Credibility and BrandEquity. European Journal of Mating, 45, 882-909. https://doi.org/10.1108/03090561111119958

\section{Copyrights}

Copyright for this article is retained by the author(s), with first publication rights granted to the journal.

This is an open-access article distributed under the terms and conditions of the Creative Commons Attribution license (http://creativecommons.org/licenses/by/4.0/). 